\title{
Size, Shape, Composition and Separation Analysis of Products from Waste Refrigerator Recycling Plants in South Korea
}

\author{
Kihong Kim ${ }^{1, * 1}$, Heechan Cho ${ }^{1, * 2}$, Jinan Jeong ${ }^{1, * 1}$ and Sookyung $\mathrm{Kim}^{2}$ \\ ${ }^{1}$ Department of Energy Resources Engineering, Seoul National University, 1 Gwanak-ro, Gwanak-gu, Seoul, Korea \\ ${ }^{2}$ Korea Institute of Geoscience and Mineral resources, 124 Gwahang-no, Yuseong-gu, Daejeon, Korea
}

With the rapid increase in the amount of waste household appliances, there is increasing awareness about finding more efficient ways to reutilize used appliances. There are several plants for recycling household appliances in Korea. The process of recycling involves several stages of shredding, followed by material separation. Given that these plants were built with the technology available at the time of construction, they may not operate at maximum efficiency even as appliances advance with technological improvements in manufacturing. Accordingly, samples were collected from a recycling plant in Korea, and plant performance was evaluated in this study for developing a more efficient recycling process. [doi:10.2320/matertrans.M2013306]

(Received August 13, 2013; Accepted October 28, 2013; Published December 6, 2013)

Keywords: waste refrigerator, household appliance, recycling, material separation

\section{Introduction}

With rapid growth in the electronic industry as well as in the standard of living, the amount of waste household appliances has increased noticeably. According to statistics from the Ministry of Environment of Korea, ${ }^{1)}$ about 550,000 tons of household appliances, including refrigerators, TVs, washing machines, and air conditioners, were manufactured in 2011. Although the lifespan of household appliances has been almost stable or increasing in some developed countries, ${ }^{2)}$ the amount of waste household appliance generation in Korea is expected to increase until 2020. ${ }^{3)}$

The basic components of household appliances consist mostly of recyclable materials such as plastics, iron, copper, and aluminum. In 2000, the Korean electronics industry signed an agreement with the Ministry of Environment to voluntarily recycle the waste generated from producing household appliances and established the Korea Association of Electronics Environment to collect and recycle postconsumer products on their behalf. In 2003, the Extended Producer Responsibility (EPR) system was enacted. Since then, there has been a significant increase in the amount of collected waste household appliances, with an average recycling rate of approximately $40 \% .^{1,4)}$ In particular, the annual amount of waste refrigerators recycled has reached 60,000 tons, which is more than half of total amount of all appliances processed in recycling plants to recover recyclable materials. ${ }^{1,4)}$

The process of recycling waste household appliances involves the following: (1) manually disassembling parts that can be extracted from appliances; (2) shredding (disintegrating) extracted parts to fine fragments; and (3) separating fragments of various individual materials using physical separation methods based on magnetic force, specific gravity, and electrostatic force.

The primary goal of shredding is to control the size of waste fragment particles for the separation processes. It is

\footnotetext{
${ }^{* 1}$ Graduate Student, Seoul National University

${ }^{* 2}$ Corresponding author, E-mail: hccho@snu.ac.kr
}

important to apply adequate stress so that the products acquire a high degree of liberation. Therefore, the shredding process has a large impact on the effectiveness of the entire recycling process. Consequently, designing an efficient shredding process is important for enhancing recycling process effectiveness.

Several studies ${ }^{5-7)}$ have been conducted for evaluating the processing of waste electrical and electronic equipment (WEEE). These studies have reviewed various WEEE treatment implementation strategies and recovery technologies and included models and simulations for improving processes by delineating the effects of material entanglement in terms of separation, material sizing, and composition analysis. Additional studies ${ }^{8-14)}$ have characterized shredded waste home appliance fragments by size, composition, and shape for developing efficient recycling processes as well as for enhancing shredder performance. In particular, advanced shredders have been developed for shrinking the shredding process to a single step. ${ }^{15,16)}$ Jian-jun et al. ${ }^{17)}$ evaluated the treatment of E-waste to select an environmentally friendly, economical, and socially acceptable treatment method. On the basis of the results of this evaluation, they suggested reselling after refurbishment for short-lifespan refrigerators and pretreatment with complete disassembly and shredding for long-lifespan refrigerators. Ruan and $\mathrm{Xu}^{18)}$ developed an environment-friendly process for recycling waste refrigerators. This process employed several high performance separation technologies to achieve a recovery rate of over $97.6 \%$.

Currently, in Korea, there are seven major recycling centers managed by the Korea Association of Electronics Environment. With the exception of two newly built facilities, these recycling centers depend on a combination of several technologies that were imported between the late 1990s and the early 2000s. Thus far, these facilities have operated without a clear understanding of the process involved. Moreover, they use old shredders that are long overdue for replacement owing to wear-and-tear and damage, which lead to high maintenance costs and inefficient separation. Furthermore, the facilities employ a four-step 


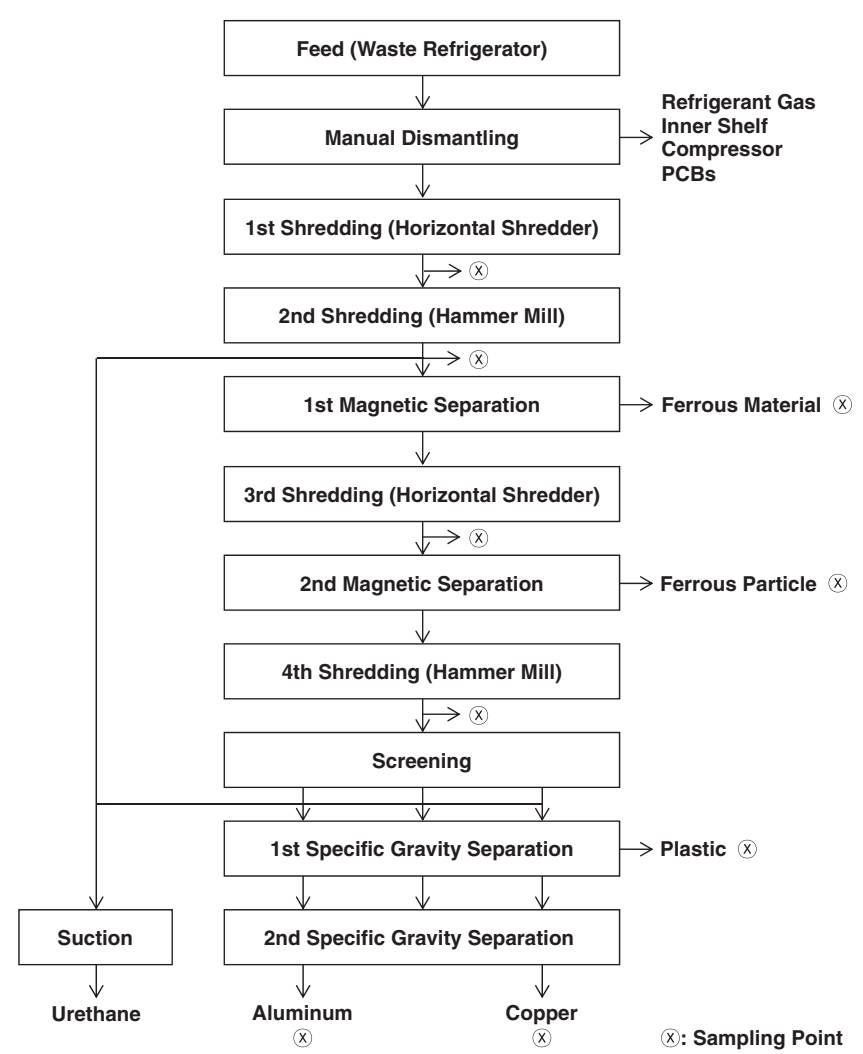

Fig. 1 Korean recycling process flowsheet.

shredding process that consumes a greater amount of energy and requires high levels of maintenance input.

Therefore, this study examined the shredding and separation processes of Korea-based recycling facilities. An analysis of the obtained results is expected to provide valuable information for developing waste refrigerator recycling processes of higher efficiency.

\section{Experimental}

\subsection{Waste refrigerator sample}

Figure 1 shows the process of a typical recycling facility currently operating in Korea. With the exception of small private companies, all recycling facilities were built and are managed by the Korea Association of Electronics Environment. Therefore, other than some minor differences, and with the exception of two recently built facilities, the facility design of these recycling centers is almost identical. Major components such as compressors, interior shelves, printed circuit boards, and storage bins are removed manually. The residual parts are then sent for mechanical shredding and material separation. There are four stages of shredding: Shredders in Stages 1 and 3 are horizontal co-axial shredders that shear the feed into small fragments. Stages 2 and 4 are hammer mills that disintegrate and crush materials by impact. A suction device is installed over a conveyor belt that transports Stage-2 shreds to Stage 3 for urethane collection. Two dry magnetic separators are installed before and after the Stage 3 shredder for collecting ferrous materials. After Stage 4 shredding, the resulting fragments are classified into three different groups through screening by size and are then sent separately to material separation units. The plastics are separated first; then, aluminum is separated from copper using a specific gravity separator. The specifications of the shredders and separators are listed in Table 1.

In total, nine samples were collected at various sampling points, as shown in Fig. 1. These include sampling after each shredding process is completed and after all materials have been separated. The amount of each sample was $5 \mathrm{~kg}$, and sampling was done twice at different times for ensuring replicability and representativeness.

\subsection{Analysis}

For a more precise and accurate analysis, the samples were manually separated into different material groups: iron, copper, aluminum, plastic, urethane, styrofoam, electric wire, and other materials (magnetic rubber and PCB). Iron and aluminum were separated using magnets, and any fragments composed of more than two different materials were considered unliberated.

Particle size distributions were measured for each separated sample to examine the changes in particle size as the shredding process proceeds. However, shredded fragments existed in various shapes, which made it difficult to determine their sizes. Accordingly, the particles were measured by their longest cord lengths using a ruler and classified into groups of $<10 \mathrm{~mm}, 10-20 \mathrm{~mm}, 20-40 \mathrm{~mm}$, $40-80 \mathrm{~mm}, 80-160 \mathrm{~mm}, 160-320 \mathrm{~mm}$, and $>320 \mathrm{~mm}$. In addition, the shape of each fragment was analyzed, and particles larger than $1 \mathrm{~mm}$ were classified into four shapes: flat, rounded, tubular, and wire.

\section{Results and Discussion}

\subsection{Results of shredded fragment analysis}

Table 2 and Fig. 2 list and show, respectively, the mass percentages of the shredded fragments by size and material. As shown in Fig. 2, fragment size decreases as the shredding process progresses from Stage 1 to Stage 4. Forty-five percent of the fragments from Stage 1 shredding were larger than $320 \mathrm{~mm}$ and $83 \%$ were larger than $160 \mathrm{~mm}$. After Stage 2 shredding, the particles were of finer sizes, with $56 \%$ of the sample in the range of $40-80 \mathrm{~mm}$. After Stage 3 shredding, $58 \%$ of the sample was in the $20-40 \mathrm{~mm}$ particle size range. After Stage 4 shredding, the proportion of fragments in the $40-80 \mathrm{~mm}$ range decreased significantly, whereas those in the $10-20 \mathrm{~mm}$ and $<10 \mathrm{~mm}$ ranges increased.

In terms of composition, there was a considerable amount of iron and urethane mixture in the Stage 1 fragments. After Stage 2 shredding, iron and urethane were completely separated from each other, attaining $99 \%$ degree of liberation. In terms of mass, iron comprised $63 \%$ of the fragments; followed by plastic at $23 \%$; aluminum at $2 \%$; and copper, electric wire, and styrofoam each less than $1 \%$. Additionally, electric wires appeared in the Stage 2 fragments because they were detached from large components, where they were hidden in Stage 1. Magnetic separation removed all iron from the Stage 2 fragments. Therefore, there was no iron in Stage 3 and 4 fragments, and plastic constituted the largest share at $74 \%$ of the total mass of these stages. 
Table 1 Specifications of each processing unit.

\begin{tabular}{|c|c|c|c|c|c|c|}
\hline Vertical shredder & Motor & Capacity & Cutter \& Hook & Shaft speed & Decelerating rate & \\
\hline Stage 1 & $380 \mathrm{~V}, 90 \mathrm{~kW} \times 2 \mathrm{EA}$ & 7.6 ton $/ \mathrm{h}$ & $\begin{array}{l}\text { L: 12EA (3Hooks) } \\
\text { R: 11EA (2Hooks) }\end{array}$ & $14 \mathrm{rpm}$ & $1 / 125$ & \\
\hline Stage 3 & $380 \mathrm{~V}, 55 \mathrm{~kW}$ & 3.6 ton $/ \mathrm{h}$ & $\begin{array}{l}\text { L: 22EA (20Hooks) } \\
\text { R: 22EA (20Hooks) }\end{array}$ & $50 \mathrm{rpm}$ & $1 / 37$ & \\
\hline Hammer mill & Motor & Capacity & V-Pulley & V-Belt & Shaft speed & Beater \\
\hline Stage 2 & $380 \mathrm{~V}, 180 \mathrm{~kW}$ & 7.6 ton $/ \mathrm{h}$ & $\begin{array}{l}\text { Motor: } 304 \mathrm{~mm} \\
\text { Driver: } 812 \mathrm{~mm}\end{array}$ & $\mathrm{D} \times 6604 \times 8 \mathrm{EA}$ & $680 \mathrm{rpm}$ & $46 \mathrm{EA}$ \\
\hline Stage 4 & $380 \mathrm{~V}, 75 \mathrm{~kW}$ & 1.8 ton $/ \mathrm{h}$ & $\begin{array}{l}\text { Motor: } 224 \mathrm{~mm} \\
\text { Driver: } 400 \mathrm{~mm}\end{array}$ & $\mathrm{SPB} \times 4250 \times 5 \mathrm{EA}$ & $972 \mathrm{rpm}$ & 44EA \\
\hline Magnetic separator & Motor & Belt speed & Magnet & Decelerating rate & & \\
\hline Stage 1 & $380 \mathrm{~V}, 2.2 \mathrm{~kW} \times 3 \mathrm{EA}$ & $75 \mathrm{~m} / \mathrm{min}$ & $4.5 \mathrm{~kW}$ & $1 / 30$ & & \\
\hline Stage 2 & $380 \mathrm{~V}, 1.5 \mathrm{~kW}$ & $15 \mathrm{~m} / \mathrm{min}$ & $3.0 \mathrm{~kW}$ & $1 / 100$ & & \\
\hline Stage 1-vibrator & $380 \mathrm{~V}, 0.75 \mathrm{~kW}$ & 0.3 ton $/ \mathrm{h}$ & $\begin{array}{l}\text { Motor: } 80 \mathrm{~mm} \\
\text { Driver: } 224 \mathrm{~mm}\end{array}$ & $\mathrm{SPA} \times 900 \times 1 \mathrm{EA}$ & $626 \mathrm{rpm}$ & \\
\hline Stage 1-blower & $380 \mathrm{~V}, 2.2 \mathrm{~kW} \times 3 \mathrm{EA}$ & & $\begin{array}{l}\text { Motor: } 125 \mathrm{~mm} \\
\text { Driver: } 150 \mathrm{~mm}\end{array}$ & $\mathrm{SPA} \times 800 \times 6 \mathrm{EA}$ & & \\
\hline Stage 2-vibrator & $380 \mathrm{~V}, 0.75 \mathrm{~kW}$ & 0.27 ton $/ \mathrm{h}$ & $\begin{array}{l}\text { Motor: } 80 \mathrm{~mm} \\
\text { Driver: } 224 \mathrm{~mm}\end{array}$ & $\mathrm{SPA} \times 1157 \times 1 \mathrm{EA}$ & $626 \mathrm{rpm}$ & \\
\hline Stage 2-blower & $380 \mathrm{~V}, 2.2 \mathrm{~kW} \times 3 \mathrm{EA}$ & & $\begin{array}{l}\text { Motor: } 112 \mathrm{~mm} \\
\text { Driver: } 160 \mathrm{~mm}\end{array}$ & $\mathrm{SPA} \times 1157 \times 6 \mathrm{EA}$ & & \\
\hline
\end{tabular}

Table 2 Mass percentage of each fragment.

\begin{tabular}{|c|c|c|c|c|c|c|c|c|c|c|c|}
\hline Sample & $\begin{array}{l}\text { Size } \\
(\mathrm{mm})\end{array}$ & $\begin{array}{c}\text { Iron } \\
(\operatorname{mass} \%)\end{array}$ & $\begin{array}{l}\text { Aluminum } \\
\text { (mass\%) }\end{array}$ & $\begin{array}{c}\text { Copper } \\
(\text { mass } \%)\end{array}$ & $\begin{array}{c}\text { Plastic } \\
(\text { mass\%) }\end{array}$ & $\begin{array}{l}\text { Urethane } \\
\text { (mass\%) }\end{array}$ & $\begin{array}{c}\text { Electric } \\
\text { Wire } \\
\text { (mass\%) }\end{array}$ & $\begin{array}{c}\text { Styrofoam } \\
\text { (mass\%) }\end{array}$ & $\begin{array}{c}\text { Iron+ } \\
\text { Urethane } \\
(\text { mass } \%)\end{array}$ & $\begin{array}{c}\text { Other } \\
\text { Mixtures } \\
(\text { mass } \%)\end{array}$ & $\begin{array}{c}\text { Sum } \\
(\operatorname{mass} \%)\end{array}$ \\
\hline $1 \mathrm{st}$ & $<10$ & 0.03 & & & & 0.66 & & 0.29 & & & 0.98 \\
\hline Shredding & $10-20$ & & & & & 0.12 & & & & & 0.12 \\
\hline \multirow[t]{5}{*}{ Products } & $20-40$ & 0.06 & 0.03 & & 0.06 & 0.20 & & 0.09 & & 0.09 & 0.52 \\
\hline & $40-80$ & 5.46 & 0.06 & & 1.44 & 1.33 & & 0.46 & & & 8.75 \\
\hline & $160-320$ & & & & 13.28 & 4.04 & & 0.20 & 19.43 & 1.85 & 38.80 \\
\hline & $>320$ & 3.00 & 4.21 & & 13.28 & & & 0.20 & 23.96 & & 44.66 \\
\hline & Sum & 9.58 & 4.30 & & 29.71 & 6.76 & & 2.89 & 44.46 & 2.31 & 100 \\
\hline 2 nd & $<10$ & & & & & 9.01 & & 0.27 & & & 9.28 \\
\hline Shredding & $10-20$ & 0.22 & 0.07 & & 0.24 & 0.44 & & 0.02 & & & 0.99 \\
\hline \multirow[t]{4}{*}{ Products } & $20-40$ & 11.02 & 0.27 & 0.13 & 3.56 & 0.86 & 0.02 & 0.07 & & 0.07 & 15.99 \\
\hline & $80-160$ & 11.26 & 0.31 & & 4.95 & & 0.42 & & & 0.46 & 17.40 \\
\hline & $160-320$ & & & & 0.27 & & 0.11 & & & 0.40 & 0.77 \\
\hline & Sum & 61.79 & 1.88 & 0.46 & 22.86 & 10.73 & 0.88 & 0.38 & & 1.02 & 100 \\
\hline $3 \mathrm{rd}$ & $<10$ & & 0.22 & & 12.68 & 4.70 & & & & & 17.60 \\
\hline Shredding & $10-20$ & & 1.20 & 0.87 & 6.89 & 2.41 & 0.05 & & & & 11.42 \\
\hline \multirow[t]{4}{*}{ Products } & $20-40$ & & 6.34 & 2.19 & 47.24 & 1.64 & 0.77 & & & & 58.18 \\
\hline & $40-80$ & & & 3.06 & 7.44 & & 1.64 & & & & 12.14 \\
\hline & $80-160$ & & & 0.55 & & & 0.11 & & & & 0.66 \\
\hline & Sum & & 7.76 & 6.67 & 74.25 & 8.75 & 2.57 & & & & 100 \\
\hline 4 th & $<10$ & & & & 23.32 & 10.22 & & & & & 33.54 \\
\hline Shredding & $10-20$ & & 2.59 & 0.61 & 18.75 & 1.22 & 0.15 & & & & 23.32 \\
\hline Products & $20-40$ & & 8.23 & 0.76 & 30.19 & 0.15 & 1.07 & & & & 40.40 \\
\hline
\end{tabular}



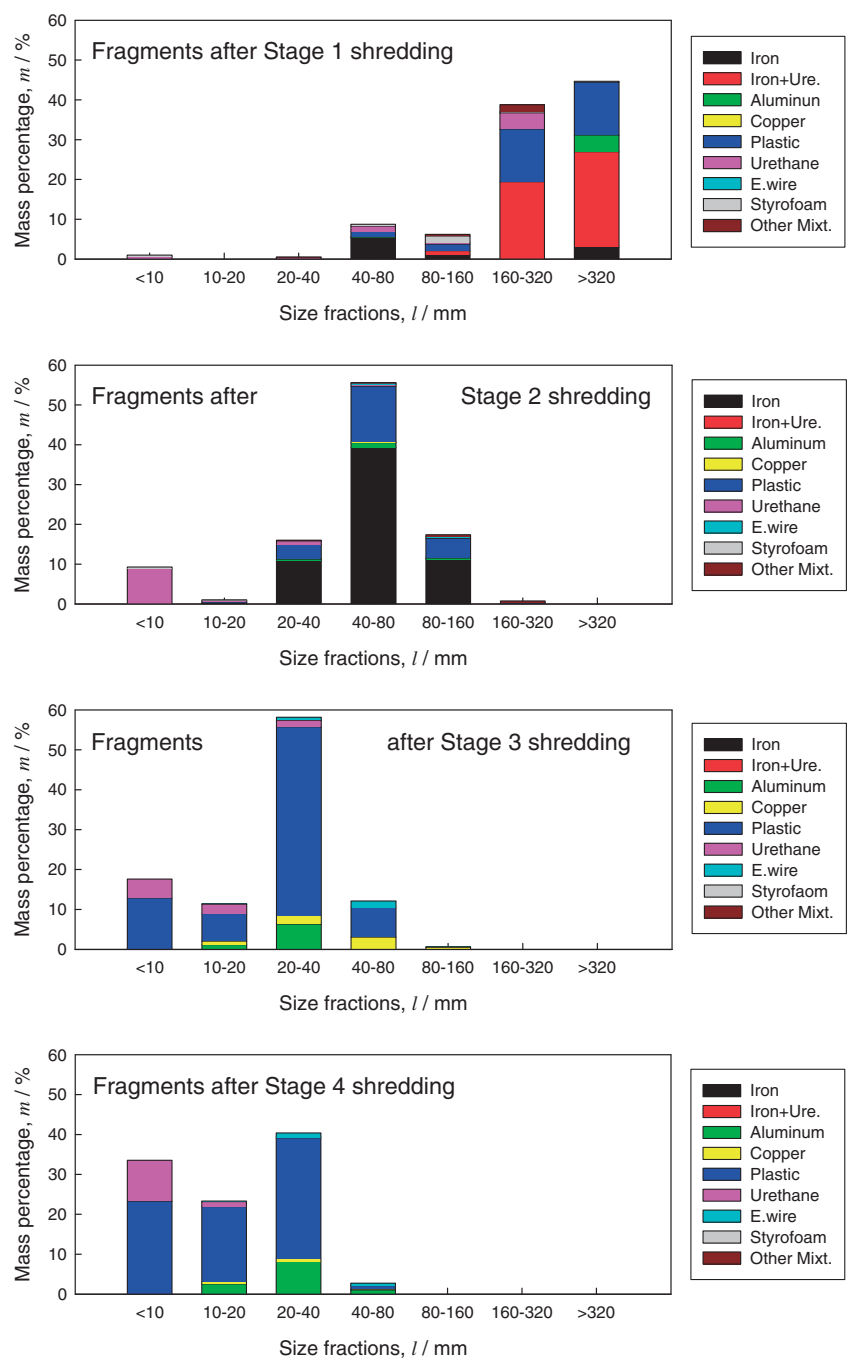

Fig. 2 Mass percentage of individual material fragments according to particle size.

In Stage 4 fragments, the mass percentages of plastics and urethane in the $<10 \mathrm{~mm}$ size range increased considerably, whereas the size distributions of copper and aluminum did not change significantly. This indicates that plastics and urethane were preferentially shredded in Stage 4.

\subsection{Results of product analysis after material separation}

The separation efficiencies of the specific gravity separators used at most recycling facilities are at their highest when the particles are narrow. Therefore, after Stage 4 shredding, the fragments were divided into three different size groups, i.e., L (large), $\mathrm{M}$ (medium), and $\mathrm{S}$ (small), by screening. Each group was sent separately through three specific gravity separators. The average particle sizes of the L, M, and S groups were 20, 15, and $10 \mathrm{~mm}$, respectively. Figure 3 shows the composition of the final products after they were separated into the three aforementioned size-based groups. Separation occurred more effectively in the larger size groups. In the case of aluminum, purity increased from 61 to $80 \%$ and finally to $93 \%$, as the particle size increased. Furthermore, the purity of copper increased from 81 to $86 \%$ and eventually to $89 \%$, as the particle size increased.
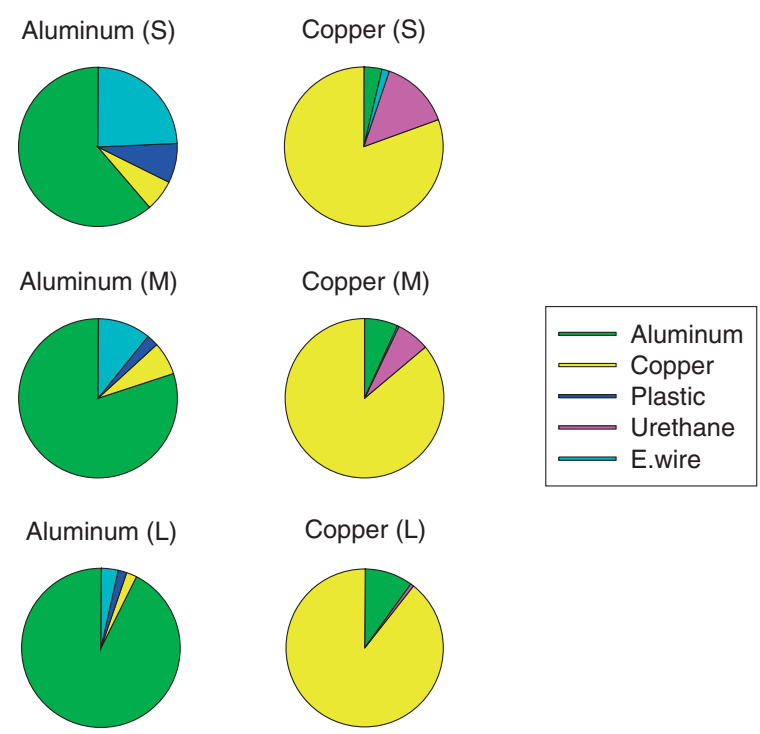

Copper (L)

Fig. 3 Composition of aluminum and copper end products.

Table 3 summarizes the results of three products plastics, aluminum, and copper - by size, composition, and mass percentage. Ninety-five percent of the plastic products were less than $40 \mathrm{~mm}$ in size and $26 \%$ were less than $10 \mathrm{~mm}$. The size distributions of copper and aluminum were coarse compared with that of plastics, with $4 \%$ of aluminum and $16 \%$ of copper particles having sizes less than $10 \mathrm{~mm}$. This indicates that plastic is weaker and is therefore shredded into finer sizes than aluminum or copper. Overall, the purities of the separated products were $91 \%$ for plastic, $86 \%$ for aluminum, and $90 \%$ for copper. The main impurities in the separated aluminum were electric wires and copper, while the separated copper was contaminated with aluminum and plastics. Obviously, electric wires, which are long and thin, did not separate well in the type of gravity separator used in the study plant. Furthermore, plastic components turned flaky after shredding, and copper components were tubular as they are used for tubing. This shape difference can interfere with gravity-based separation. Therefore, additional separation considering this shape difference can improve product purity.

There are two installed magnetic separators in all; one each after Stages 1 and 3. The analysis results of the magnetic products of these two separators are summarized in Table 4. Among the products recovered from Stage 1 magnetic separation, $83 \%$ was pure ferrous material and $14 \%$ was a mixture containing ferrous material. The remaining $3 \%$ was made up of nonmagnetic materials. Stage 3 shredding products were much finer in size. Therefore, the magnetic products recovered after Stage 3 shredding were mostly in the $<10 \mathrm{~mm}$ size range; $47 \%$ of these products was iron and about $16 \%$ was made up of nonferrous metals. The proportion of impurities was much higher, probably due to the entrainment of fine particles because Stage 3 fragments were considerably smaller in size than Stage 1 fragments.

\subsection{Results of mixture analysis}

Refrigerators have a relatively simple structure with few materials and can reach the fully liberated state relatively easily. This is because components such as printed circuit 
Table 3 Size and composition analysis of product streams after material separation.

\begin{tabular}{|c|c|c|c|c|c|c|c|c|c|}
\hline Sample & $\begin{array}{l}\text { Size } \\
(\mathrm{mm})\end{array}$ & $\begin{array}{c}\text { Iron } \\
(\text { mass } \%)\end{array}$ & $\begin{array}{c}\text { Aluminum } \\
\text { (mass\%) }\end{array}$ & $\begin{array}{l}\text { Copper } \\
(\operatorname{mass} \%)\end{array}$ & $\begin{array}{l}\text { Plastic } \\
(\text { mass\%) }\end{array}$ & $\begin{array}{l}\text { Urethane } \\
\text { (mass\%) }\end{array}$ & $\begin{array}{l}\text { Electric Wire } \\
\quad(\operatorname{mass} \%)\end{array}$ & $\begin{array}{l}\text { Styrofoam } \\
\text { (mass\%) }\end{array}$ & $\begin{array}{c}\text { Sum } \\
(\operatorname{mass} \%)\end{array}$ \\
\hline \multirow[t]{6}{*}{ Plastic } & $<10$ & & 0.84 & & 23.77 & 0.38 & 0.04 & & 25.03 \\
\hline & $10-20$ & & 1.22 & & 23.69 & 0.23 & 0.30 & 0.08 & 25.52 \\
\hline & $20-40$ & & 3.11 & & 40.63 & 0.08 & 1.14 & & 44.96 \\
\hline & $40-80$ & & 0.61 & & 3.34 & & 0.46 & & 4.41 \\
\hline & $80-160$ & & & & & & 0.08 & & 0.08 \\
\hline & Sum & & 5.78 & & 91.43 & 0.69 & 2.02 & 0.08 & 100 \\
\hline \multirow[t]{5}{*}{ Aluminum } & $<10$ & & 3.58 & 0.04 & 0.37 & & 0.07 & & 4.06 \\
\hline & $10-20$ & & 37.31 & 1.02 & 1.10 & & 1.24 & & 40.67 \\
\hline & $20-40$ & & 42.20 & 4.45 & 0.22 & & 3.87 & & 50.74 \\
\hline & $40-80$ & & 3.14 & 0.66 & & & 0.73 & & 4.53 \\
\hline & Sum & & 86.23 & 6.17 & 1.69 & & 5.91 & & 100 \\
\hline \multirow{4}{*}{ Copper } & $10-20$ & & 4.01 & 43.48 & & & 0.06 & & 47.55 \\
\hline & $20-40$ & & & 33.23 & & & 0.12 & & 33.35 \\
\hline & $40-80$ & & & 2.95 & & & & & 2.95 \\
\hline & Sum & & 5.19 & 90.15 & 4.36 & & 0.30 & & 100 \\
\hline
\end{tabular}

Table 4 Size and composition analysis of magnetic products.

\begin{tabular}{|c|c|c|c|c|c|c|c|c|c|c|}
\hline Sample & $\begin{array}{l}\text { Size } \\
(\mathrm{mm})\end{array}$ & $\begin{array}{c}\text { Iron } \\
(\text { mass } \%)\end{array}$ & $\begin{array}{l}\text { Magnetic } \\
\text { Products } \\
\text { Mixtures } \\
(\operatorname{mass} \%)\end{array}$ & $\begin{array}{c}\text { Aluminum } \\
\text { (mass\%) }\end{array}$ & $\begin{array}{c}\text { Copper } \\
\text { (mass\%) }\end{array}$ & $\begin{array}{c}\text { Plastic } \\
(\text { mass } \%)\end{array}$ & $\begin{array}{l}\text { Urethane } \\
\text { (mass\%) }\end{array}$ & $\begin{array}{c}\text { Electric } \\
\text { Wire } \\
(\text { mass } \%)\end{array}$ & $\begin{array}{c}\text { Styrofoam } \\
\text { (mass\%) }\end{array}$ & $\begin{array}{c}\text { Sum } \\
(\operatorname{mass} \%)\end{array}$ \\
\hline $1 \mathrm{st}$ & $<10$ & 35.23 & 0.13 & & & 0.61 & 0.58 & & 0.58 & 37.13 \\
\hline Magnetic & $10-20$ & 20.03 & 2.09 & 0.03 & & & & & & 22.15 \\
\hline \multirow[t]{3}{*}{ Products } & $20-40$ & 23.02 & 9.06 & & 0.16 & & & & & 32.24 \\
\hline & $80-160$ & 0.55 & 1.19 & & & & & 0.35 & & 2.09 \\
\hline & Sum & 83.45 & 14.11 & 0.03 & 0.19 & 0.61 & 0.58 & 0.45 & 0.58 & 100 \\
\hline 2nd & $<10$ & 47.57 & & & & 5.29 & 5.29 & & 5.25 & 63.41 \\
\hline Magnetic & $10-20$ & 2.10 & 2.32 & 0.07 & & 0.14 & & & & 4.64 \\
\hline \multirow[t]{3}{*}{ Products } & $20-40$ & 12.72 & 12.83 & 0.36 & 0.11 & 1.88 & & 0.14 & & 28.04 \\
\hline & $40-80$ & 0.62 & 1.38 & & 0.14 & 0.22 & & 0.11 & & 2.46 \\
\hline & Sum & 64.46 & 16.52 & 0.43 & 0.25 & 7.54 & 5.29 & 0.25 & 5.25 & 100 \\
\hline
\end{tabular}

boards and compressor motors are removed manually before being subjected to the shredding process. Even after shredding, fragments that consist of two or more materials were rarely observed in this study. Table 5 summarizes the results of the mixture analysis. The mixture of iron and urethane accounted for $45 \%$ of the Stage 1 fragments. Two percent of the total mass was accounted for by the mixture of aluminum and electric wires with a mass ratio of $10: 1$. About $0.1 \%$ of the mass was accounted for by screw bolts containing pieces of plastics, and $53 \%$ of the fragments were pure.

After Stage 2 shredding, iron, urethane, aluminum, and electric wires were completely liberated from each other and reached $99 \%$ degree of liberation. About $0.1 \%$ of the mass was a mixture of plastics and screws, while the mixture of iron and copper comprised $0.9 \%$, which disappeared after Stage 3 shredding. Mixed products in the magnetic separa- tions of Stages 1 and 2 constituted of plastics-screws and iron-copper mixtures as well.

\subsection{Material balance estimation}

For analyzing the material balance of the entire circuit, it is necessary to measure the composition of material flowed into and out of a unit. However, in this study, only sampling was performed, and the material balance was estimated based on the compositions of individual products. The results are listed and shown, respectively, in Table 6 and Fig. 4. The percentages of iron, aluminum, copper, plastic, and urethane recovered upon completion of the separation process were $100,67,80,98$, and 87 , respectively. Notably, the recovery of iron was $100 \%$. Aluminum has the lowest recovery percentage because a considerable amount of aluminum is mislocated in the plastic products, probably owing to aluminum's low density. The recovery of copper was about 
Table 5 Results of mixture analysis.

\begin{tabular}{|c|c|c|c|c|c|c|c|c|c|c|c|c|c|c|}
\hline \multirow[b]{2}{*}{ Sample } & \multirow{2}{*}{$\begin{array}{l}\text { Size } \\
(\mathrm{mm})\end{array}$} & \multicolumn{3}{|c|}{ Iron+Urethane } & \multicolumn{3}{|c|}{ Plastic+Screw } & \multicolumn{3}{|c|}{ Aluminum+E.wire } & \multicolumn{3}{|c|}{ Iron+Copper } & \multirow{2}{*}{$\underset{(\operatorname{mass} \%)}{\operatorname{Sum}}$} \\
\hline & & $\begin{array}{c}\text { Iron } \\
(\operatorname{mass} \%)\end{array}$ & $\begin{array}{c}\text { Ureth. } \\
\text { (mass\%) }\end{array}$ & $\underset{(\operatorname{mass} \%)}{\operatorname{Sum}}$ & $\begin{array}{c}\text { Plastic } \\
(\text { mass\%) }\end{array}$ & $\begin{array}{c}\text { Screw } \\
(\text { mass } \%)\end{array}$ & $\underset{(\operatorname{mass} \%)}{\operatorname{Sum}}$ & $\begin{array}{l}\text { Alumi. } \\
\text { (mass\%) }\end{array}$ & $\begin{array}{c}\text { E.wire } \\
(\text { mass } \%)\end{array}$ & $\begin{array}{c}\text { Sum } \\
(\operatorname{mass} \%)\end{array}$ & $\begin{array}{c}\text { Iron } \\
(\text { mass } \%)\end{array}$ & $\begin{array}{c}\text { Copper } \\
\text { (mass\%) }\end{array}$ & $\underset{(\operatorname{mass} \%)}{\operatorname{Sum}}$ & \\
\hline Shredding & $10-20$ & & & & & & & & & & & & & \\
\hline \multirow[t]{6}{*}{ Products } & $20-40$ & & & & 0.03 & 0.06 & 0.09 & & & & & & & 0.09 \\
\hline & $40-80$ & & & & & & & & & & & & & \\
\hline & $80-160$ & 0.87 & 0.20 & 1.07 & & & & 0.29 & 0.09 & 0.38 & & & & 1.45 \\
\hline & $160-320$ & 17.61 & 1.82 & 19.43 & & & & 1.73 & 0.12 & 1.85 & & & & 21.28 \\
\hline & $>320$ & 21.88 & 2.08 & 23.96 & & & & & & & & & & 23.96 \\
\hline & Sum & 40.36 & 4.10 & 44.46 & 0.03 & 0.06 & 0.09 & 2.02 & 0.20 & 2.22 & & & & 46.77 \\
\hline 2nd & $<10$ & & & & & & & & & & & & & \\
\hline Shredding & $10-20$ & & & & & & & & & & & & & \\
\hline \multirow[t]{4}{*}{ Products } & $20-40$ & & & & 0.02 & 0.04 & 0.07 & & & & & & & 0.07 \\
\hline & $80-160$ & & & & & & & & & & 0.24 & 0.22 & 0.46 & 0.46 \\
\hline & $160-320$ & & & & & & & & & & 0.20 & 0.20 & 0.40 & 0.40 \\
\hline & Sum & & & & 0.02 & 0.04 & 0.07 & & & & 0.49 & 0.46 & 0.95 & 1.02 \\
\hline $1 \mathrm{st}$ & $<10$ & & & & & & & & & & 0.06 & 0.06 & 0.13 & 0.13 \\
\hline Magnetic & $10-20$ & & & & 0.64 & 1.25 & 1.90 & & & & 0.10 & 0.10 & 0.19 & 2.09 \\
\hline \multirow[t]{4}{*}{ Products } & $20-40$ & & & & 2.25 & 3.21 & 5.46 & & & & 1.80 & 1.80 & 3.60 & 9.06 \\
\hline & $40-80$ & & & & 0.32 & 0.42 & 0.74 & & & & 0.45 & 0.45 & 0.90 & 1.64 \\
\hline & $80-160$ & & & & & & & & & & 0.61 & 0.58 & 1.19 & 1.19 \\
\hline & Sum & & & & 3.21 & 4.89 & 8.10 & & & & 3.02 & 2.99 & 6.01 & 14.11 \\
\hline 2 nd & $<10$ & & & & & & & & & & & & & \\
\hline Magnetic & $10-20$ & & & & 0.72 & 1.05 & 1.78 & & & & 0.29 & 0.25 & 0.54 & 2.32 \\
\hline Products & $20-40$ & & & & 3.62 & 3.30 & 6.92 & & & & 3.01 & 2.90 & 5.91 & 12.83 \\
\hline
\end{tabular}

Table 6 Material balance estimation.

\begin{tabular}{|c|c|c|c|c|c|c|c|c|}
\hline Product & Iron & Aluminum & Copper & Plastic & Urethane & Electric wire & Styrofoam & Sum \\
\hline \multicolumn{9}{|l|}{ (Input) } \\
\hline Feed & 56.20 & 4.27 & 1.78 & 31.99 & 4.41 & 0.95 & 0.40 & 100 \\
\hline \multicolumn{9}{|l|}{ (Output) } \\
\hline Magnetic Products & 56.20 & 0.02 & 0.11 & 0.35 & 0.33 & 0.26 & 0.33 & 57.60 \\
\hline Aluminum Products & & 2.84 & 0.26 & 0.08 & & 0.20 & & 3.38 \\
\hline Plastic Products & & 1.34 & & 31.48 & 0.24 & 0.49 & 0.07 & 33.62 \\
\hline Urethane Products & & & & & 3.84 & & & 3.84 \\
\hline (Recovery) & $100 \%$ & $67 \%$ & $80 \%$ & $98 \%$ & $87 \%$ & & & \\
\hline
\end{tabular}

$80 \%$ owing to incomplete liberation and separation. A few copper fragments were attached to iron, which were then recovered by magnetic separation. Furthermore, a few hollow copper tubes were misplaced in the aluminum products.

\subsection{Results of shape analysis}

Table 7 and Fig. 5 summarize and show, respectively, shape-based sample reclassification. Flat particles comprised the greatest quantity of Stage 1, 3, and 4 fragments. There were fewer flat particles in Stage 2 fragments. The plastics used in refrigerators are panels and have lower ductility than metal. Therefore, they break easily under shear (co-axial shredder) or impact (hammer mill). This means that most plastic particles maintained flat shapes while ductile materials, which do not break, instead rolled up into cylindrical or rounded shapes. Iron components, which are used as skeletons in refrigerators, were flat initially. Owing to their ductile nature, they were torn apart and took cylindrical or rounded shapes during Stages 1 and 2 shredding. Copper and aluminum pipes are used for refrigerant transportation. Therefore, copper components retained their tubular form through the shredding stages. In contrast, a considerable 


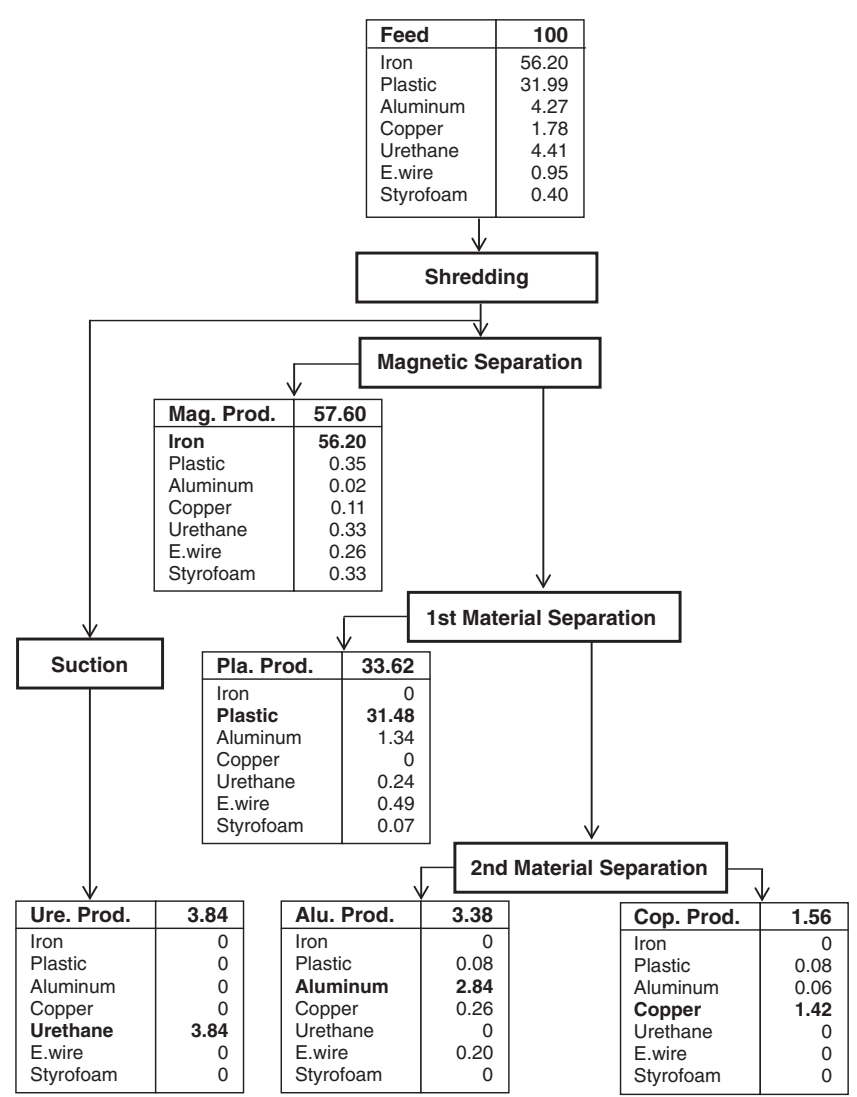

Fig. 4 Material balance estimation.

amount of aluminum is flat owing to its high ductility. Urethane is relatively easily disintegrated and produced as rounded particles throughout the shredding stages.

Therefore, it can be highly advantageous to incorporate these shape differences into the process flow for material separation. There are several physical separation methods that can be used for this purpose. For example, flowing film separators such as concentrating tables can be used for separating rounded particles that can roll better than flat particles on a slope. Also, a settling-type device can be used for separating flat particles because these particles have a lower settling rate owing to their higher resistance to flow. For exploring the possibility of using air tables for shapebased separation, simple tests were conducted using a mixture of electric wires, flat plastics, rounded aluminum particles, and tubular copper. Figure 6 shows the locations of the mixture components after air tabling for certain duration. It can be seen that electric wires show a distinct separation pattern. This indicates a good possibility of shape-differencebased material separation; however, further tests are required for complete analysis.

\subsection{New improved process}

It was found that there was little size reduction of copper and aluminum in Stage 4 shredding, but plastics and urethane were reduced into finer particles. Therefore, Stage 4 shredding may not be necessary because most materials were liberated after Stage 3 shredding.

There are several high-performance shredders that can shred waste refrigerators into fine sizes without multi-step shredding. For certifying the possibility using such shredders,
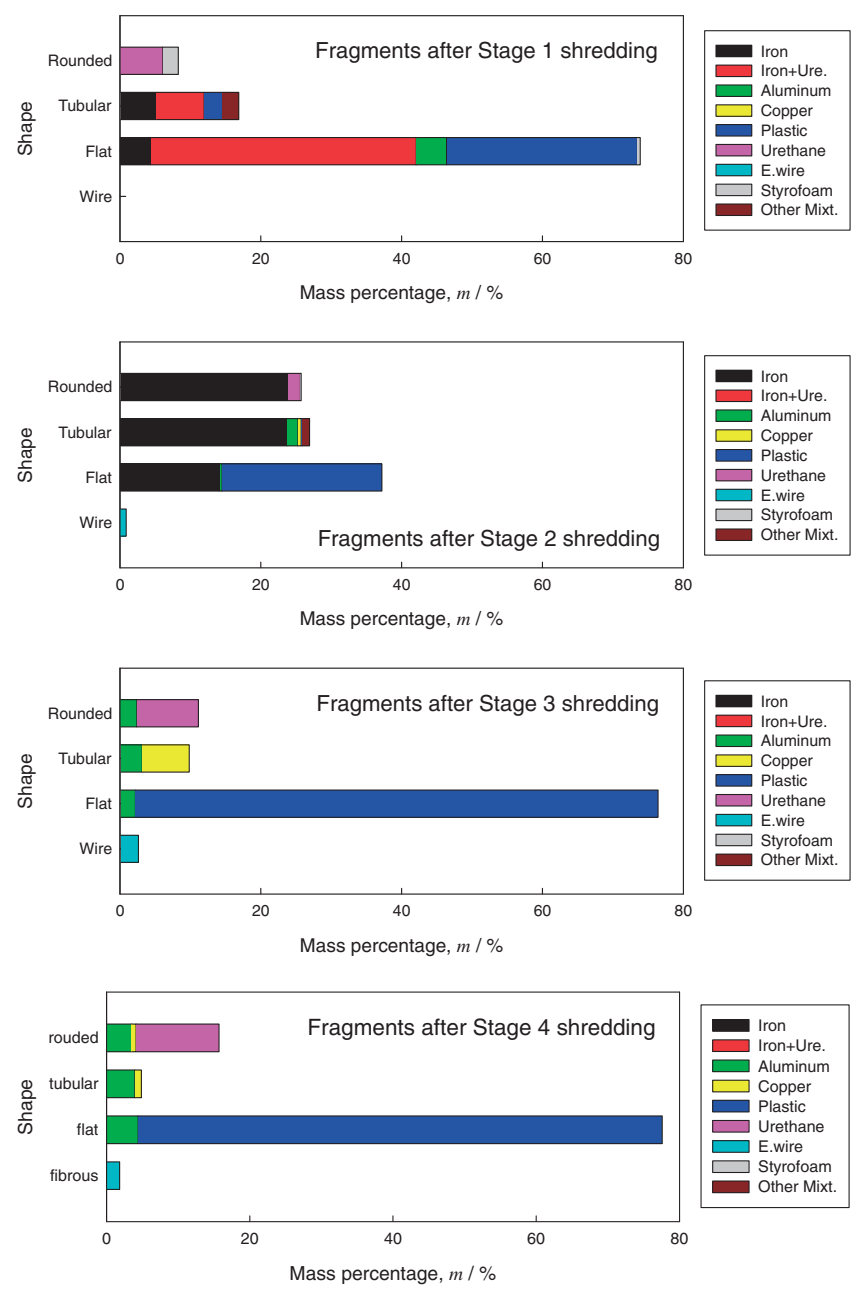

Fig. 5 Shape analysis of four-stage shredding products.

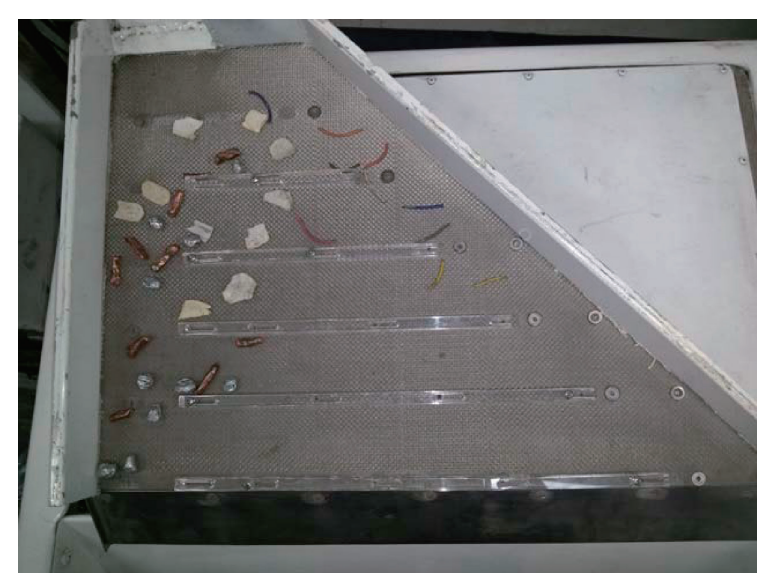

Fig. 6 Air table separation of electric wires.

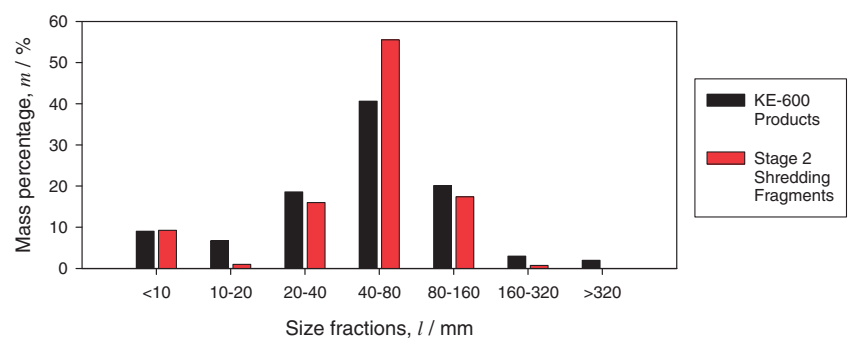

Fig. 7 Size distributions of high-performance shredding products and Stage 2 products. 


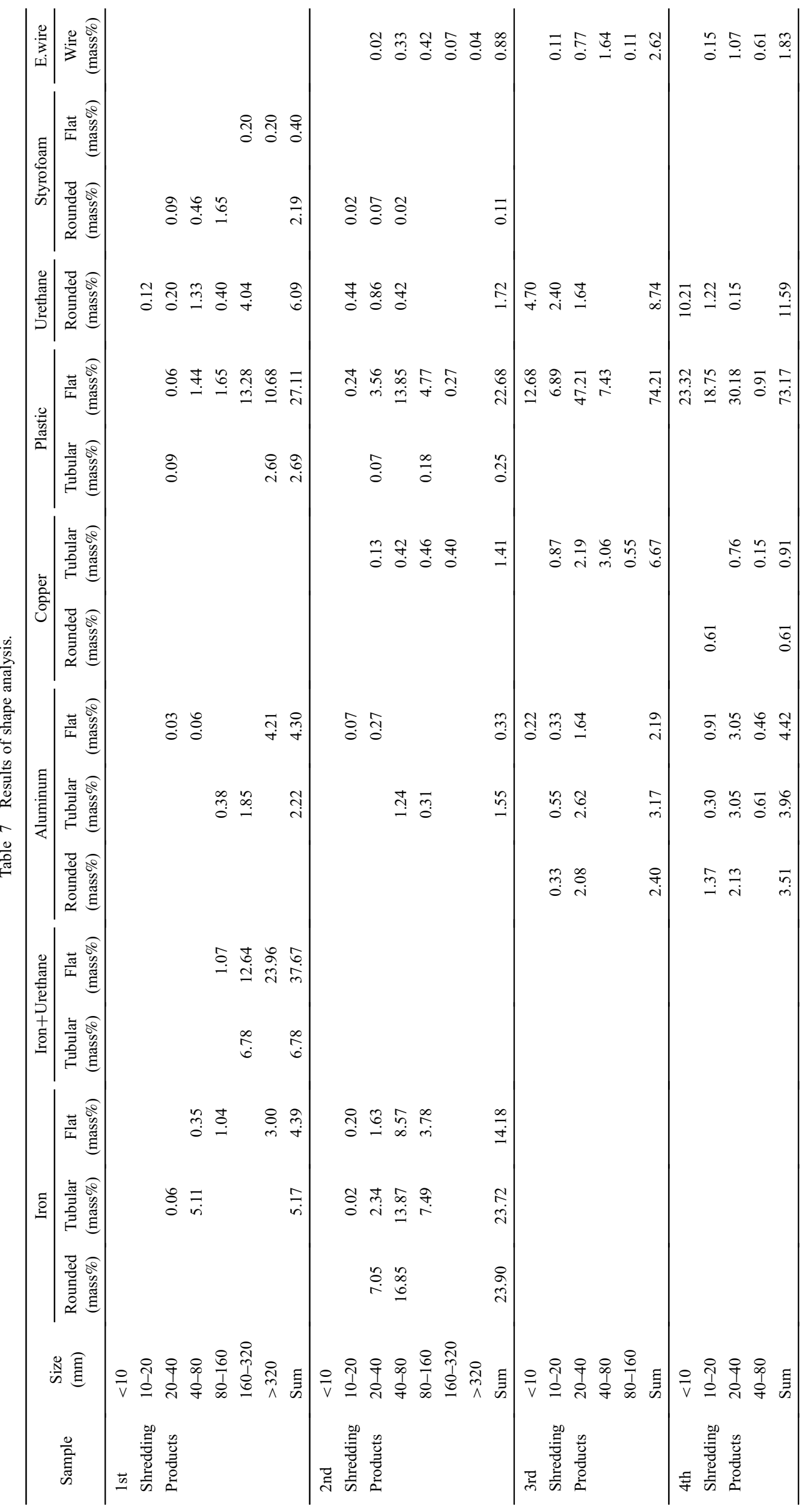




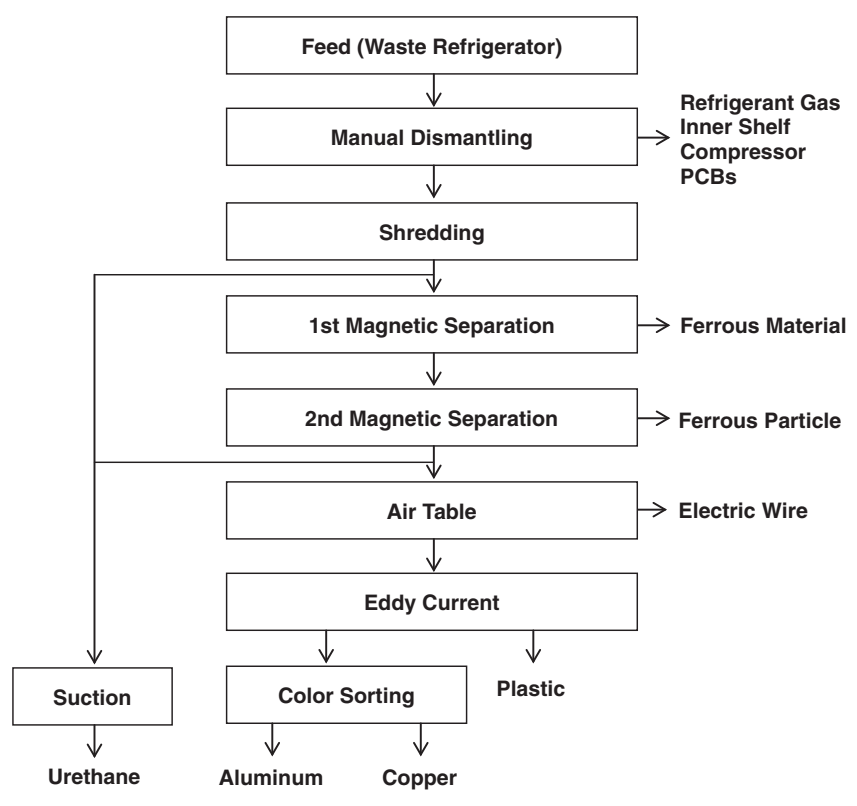

Fig. 8 Improved process flowsheet.

shredding tests were carried out using KE-600, a high-speed vertical shredder made by Kubota, Japan. The results are shown in Fig. 7. It can be seen that the product size distribution is very similar to that of Stage 2 products. This suggests that the current four-stage shredding process can be replaced with a one-stage shredding process that employs a high-speed vertical shredder. Furthermore, there is a need for improving the material separation efficiency.

Figure 8 shows one possible process scheme for achieving better energy and separation efficiencies. The existing fourstage shredding process is consolidated into a single shredding process using a high-speed vertical shredder. A magnetic separator is used for separating iron, and a pneumatic separator is used for separating urethane. Air table separation is employed for the shape-difference-based separation of electric wires after magnetic separation because there was a considerable amount of electric wires, which interfere with separation of other materials in subsequent processes.

\section{Conclusions}

This study examined the mechanical shredding and separation processes employed in Korea-based, currently operating recycling facilities. The goal was to develop an alternative method that shreds efficiently and enhances the recovery of valuable materials from waste refrigerators. The shredded fragments and final products were sampled and their characteristics were analyzed in terms of size, composition, degree of liberation, and shape. As a result, the following conclusions were arrived at.

Iron-urethane mixture accounted for about $44 \%$ of the Stage 1 products. This mixture was not found after Stage 2, indicating that Stage 2 shredding was sufficient for separating these materials from each other. There were very small amounts of plastics/screw and iron/copper after Stage 2 shredding. After Stage 3 shredding, no material was found to be in a mixed state, indicating that all materials were fully liberated. Stage 4 shredding only further reduced the particle sizes of the plastics and urethane. An analysis of the material separation showed that separation becomes difficult as the particle size decreases. An analysis of the shredded fragment shapes showed that flat iron components became rounded or cylindrical as shredding proceeded. Copper and aluminum, which are mainly used for pipes in refrigerators, took tubular forms in the initial stage of shredding. They became cylindrical or rounded toward the later stages of shredding. Plastics, which are easily shredded, remained flat after shredding. In contrast, urethane particles were rounded after shredding.

On the basis of these results, an improved process has been suggested. The existing four-stage shredding process has been consolidated into a single shredding process using a high-performance shredder. For improving the separation efficiency, the adoption of eddy current and color sorting is suggested. Air table separation is recommended for separating electric wires based on the results of shape analysis. Lab-scale and pilot-scale studies of material separators are in progress.

\section{Acknowledgements}

This study was supported by the R\&D Center for Valuable Recycling (Global-Top Environmental Technology Development Program) funded by the Ministry of Environment (Project No.: GT-12-C-01-330-0).

\section{REFERENCES}

1) Ministry of Environment of Korea: Statistics for compulsory recycling performance from 2003 to 2011 (in Korean).

2) M. Oguchi, S. Murakami, T. Tasaki, I. Daigo and S. Hashimoto: J. Indust. Eco. 14 (2010) 613-626.

3) S. Kim, M. Oguchi, A. Yoshida and A. Terazono: Waste Manag. 33 (2013) 474-483.

4) Korea Association of Electronics Environment: Statistics for recycling amount from 2000 to 2010 (in Korean).

5) M. B. Castro, J. A. M. Remmerswaal, J. C. Brezet, A. V. Schaik and M. A. Reuter: Int. J. Miner. Process. 75 (2005) 255-281.

6) G. Coates and S. Rahimifard: Waste Manag. 29 (2009) 44-53.

7) W. He, G. Li, X. Ma, H. Wang, J. Huang, M. Xu and C. Huang: J. Hazard. Mater. B 136 (2006) 502-512.

8) L. Aboussouan, P. Russo, M. N. Pons, D. Thomas, J. P. Birat and D. Leclerc: Powder Technol. 105 (1999) 288-294.

9) L. Jianxiong, P. Juntao, Y. Bangcheng and H. Jie: IERI Procedia 1 (2012) 146-154.

10) J. Kirchner, G. Timmel and G. Schubert: Powder Technol. 105 (1999) 274-281.

11) G. Martinho, A. Pires, L. Saraiva and R. Ribeiro: Waste Manag. 32 (2012) 1213-1217.

12) S. Sander, G. Schubert and G. Timmel: Powder Technol. 122 (2002) $177-187$.

13) S. Sander, G. Schubert and H.-G. Jäckel: Int. J. Miner. Process. 74S (2004) S385-S393.

14) M. Schlummer, L. Gruber, A. Maurer, G. Wolz and R. V. Eldik: Chemosphere 67 (2007) 1866-1876.

15) T. Matsuto, C. H. Junga and N. Tanaka: Waste Manag. 24 (2004) 425436.

16) M. Oguchi, H. Sakanakura, A. Terazono and H. Takigami: Waste Manag. 32 (2012) 96-103.

17) J.-j. Deng, X.-f. Wen and Y.-m. Zhao: J. China Univ. Mining \& Technol. 18 (2008) 454-458.

18) J. Ruan and Z. Xu: Waste Manag. 31 (2011) 2319-2326. 